Ann. Génét. Sél. anim., I978, 10 (3), 329-342.

\title{
A possible genetic interpretation of the colour variants in the fleece of the Gotland and Goth sheep
}

\section{S. ADAlSTEINSSON, J. J. I,AUVERGNe(*), J. G. BOYAZOGLU(**) et M. L. RYDER(***)}

\author{
Agricultural Research Institute, \\ Keldnaholt v/Vesturlandsveg, Reykjavik, Islande \\ (*) Département de Génétique animale, \\ Centre national de Recherches zootechniques, I.N.R.A., \\ $7835^{\circ}$ Jouy-en-Josas, France, \\ (**) Department of Agricultural Technical Services, \\ Pretoria, Republic of South Africa \\ (***) A.R.C. Animal Breeding Research Organisation, \\ West Mains Road, Edinburgh, EH9 $3 \mathrm{JQ}$, Great Britain
}

\section{Summary}

The paper describes colours of 79 adults and 184 lambs in 6 flocks of the ancient Swedish short-tailed, horned Goth breed of sheep. Of the adults, 36 were grey and 43 of a near-white colour, while 85 of the lambs were grey and 99 light-coloured. The light coloured lambs with limited amount of white markings showed two colour patterns, one a lightgrey with white belly, termed "grey mouflon ", and the other a mixture of light steel grey and tan, termed " agouti ".

White markings were common in all flocks, and extensive white markings interfered with the classification of the main colours in some of the flocks.

On the basis of the observations, on the Goth sheep which contained some pedigree information, and on available observations from crosses of improved grey Gotland sheep and Shetland sheep in Scotland, together with a review of the literature, the suggestion is put forward that the grey colour in the ancient Goth sheep and in the improved Gotland sheep is caused by a new allele at the $A$ gouti locus, $A^{g g}$ (Gotland grey), if not $A^{g}$ (icelandic grey). The "grey mouflon " colour of the Goth sheep is caused by another, previously unknown allele, $A^{l} g$ ( $l g$ for light grey) at the $A$ gouti locus. Some white animals may be $A^{l g} A^{l} g$ or even carry the $A^{w h}$ gene for tan or white.

\section{I. - Introduction}

The understanding of colour inheritance in sheep has been helped by the demonstration of a multi-allelic series at the Agouti $(A)$ locus (ADALsTeinsson, I960; BRooker and Doling, I969; Adalsteinsson, r970) and by the recent 
analysis of the extension locus $(E)$ (LAUVERGNE, I975). The studies support the conclusion of SEARLE (I968) that different mammals have homologous loci.

The colour of sheep, however, presents certain features that have not yet been elucidated, in particular the existence of several kinds of grey, the extent to which these are attributable to the $A$ gouti locus not being known (ADALSTEInsson, I970).

Colour inheritance studies in the improved Gotland breed were first carried our by LöFVENBERG and JOHANSSON (I952), and later by SELERUD (1955), SkARMAN (I96r, I963a, I963b), and EBBERSTEN and SkARMAN (I976). All these studies showed a wide range of shades of grey colour, although selection against the lightest and darkest extremes have been carried out for several decades.

The predecessor of the improved grey Gotland breed is the old horned Goth breed, which was on the verge of extinction in the nineteen forties, but is now being preserved. The Goth sheep show a still wider range of grey shades than the improved Gotland breed.

The aim of the present study was to examine the type of grey in the improved Gotland breed and relate it to grey colour observed in other breeds, and at the same time to attempt a genetic interpretation of the wide range of grey shades in the Goth sheep. For this purpose the authors visited Gotland in June, I976 and made observations on the colour variation in the Goth sheep. At the same time visits were made to some breeders of the improved Gotland breed for visual inspection of the colour shades present there. These observations, together with observations on crosses between improved Gotland sheep and Shetland sheep in Scotland form the basis for the conclusions of the present paper.

\section{II. - Review of the grey coloration in domestic sheep, with reference to the Gotland breed and its various colours}

\section{A. - The grey colour in breeds other than the Gotland}

If one regards grey as deriving from a mixture of black and white fibres, it is possible at the moment to distinguish three genetically controlled kinds of grey: lethal grey, progressive juvenile whitening, and grey as an Agouti factor.

Lethal grey (in which the animals are grey at birth) was first studied in the Turcana breed of Romania by CoNSTANTINESCU (I926) then in the Karakul (GLEMBOTSKy et al., I934). Among numerous works devoted to it are reviews by SERRA (I948) and RAE (I956).This is a mutation which when heterozygous is epistatic to other colour genes, producing grey through an admixture of white fibres, and when homozygous is lethal. In this, gastric troubles about the time of weaning are followed by death. On a black base this gene gives grey, while on a red base it gives a kind of lilac, both colours being exploited in Karakul furriery.

Studies on progressive whitening were summarised by SERRA (I948) who listed several types under the names progressive whitening or silvering, which develop in breeds with dominant (Karakul) as well as recessive (black Wensleydale) pigment.

This whitening occurs regularly in red breeds (Solognote) and often in black breeds (Bizet and Karakul), but not in all animals. ZAHARIA (I939) for example showed that certain Turcana sheep became grey, while other remained black all their life. The way in which this difference is inherited has not been studied in detail. 
The Agouti grey factor has been demonstrated by Adalsteinsson (I96o and 1970 ) in the Icelandic breed. At birth, the grey animals are distinguished from all black ones by light marks around the muzzle and the eyes, as well as the presence of a white underwool on the scrotum, and in the inguinal region. The underwool develops with age to give a grey fleece at about four to five months. The expression of the gene $A^{g}$ is variable, and ADALSTEInsson (I970) distinguishes seven degrees at birth. The homozygous $A^{g} A^{g}$ lambs were found to be born light grey, while the heterozygous lambs usually were born dark grey.

Observations and test mating carried our by RYDER and al. (1974) with Orkney sheep (thought to have affinities with the Scandinavian type) accorded with the interpretation that the grey gene $A^{g}$, originally designated $A_{2}$ by AdALsTEInsson was also present in this breed.

In the review of Norwegian work by BERGE (1964) (summarised in English by RYDER and STEPHENSON, r968) the mixture of black and white fibres (grey) caused by this gene is termed "black skimlet", and the mixture of brown and white fibres " brown skimlet".

\section{B. - History of the Gotland breed}

Until the nineteenth century there was in Sweden, as elswhere in Scandinavia, a population of primitive small Sheep, with coarse wool, and a short tail, which were often horned and showed a variety of colours. This type is named the northern short-tail group of Sheep. In Sweden this original population has been gradually replaced by meat breeds mainly from Britain, so that by the nineteen forties the ancient type was found mainly on the island of Gotland (EKMAN, I938, I964; HALI,ANDER, I976; RYDER, I968, I974).

Starting immediately after World War II the unimproved breed changed gradually into the improved Gotland which has the dual purposes of meat and furskin.

Fashion in furriery created a demand for grey skins from lambs four or five months old, and a system or performance testing and skin marketing has developed with the help of advisers from the Ministry of Agriculture. The methods used and the results obtained were described by SkÅmAN (I96r, I963a and b) and were summarised by GAHNE et al. (I975).

The number of Improved Gotland sheep has therefore increased from I 70 ooo in 1962 to 300 ooo today, and it now forms $90 \mathrm{p}$. Ioo of the sheep population of Sweden (RYDER, I970). In comparison with the original type, the improvement has involved a loss of horns, and the production of a fleece that has uniformity of structure and colour.

Such success has been achieved in the replacement of the old breed with the new variety that the ancient type, horned and variegated was on the verge of extinction when several enthusiasts endeavoured to safeguard it in the nineteen sixties (EDBERG, I974).

In I973, according to the last author, the number of mature individuals of this relic breed was around 400 animals, of which two hundred are in the island of Gotland in which it originated. These sheep retain the horns and a great variety of colour shades. Except at Skansen Zoo and in the Jakobsson flock on Lilla Karlsö small unimproved flocks often run alongside improved animals.

For the relic variety, EDBERG (I974) proposes the Swedish name Gutefar which in English would be called the Goth Sheep, instead of the previously used 
name behornade gotländska utegangsfären i.e. horned Gotland sheep kept outside all the time. The name given to the improved type is: Gotlands utegangstar, i.e. outdoor Gotland Sheep, or more simply Gotlands fair. In English, the improved variety is termed simply „, Gotland Sheep" (Mason, I969). In French we propose Gotlandais for the improved variety, and Gothique for the relic type.

\section{C. - The colour types of Gotland sheep as described by previous authors}

\section{Descriptive}

EKMAN (I938, I964) was able to place the animals in three colour categories: black, grey and white. The grey sheep were moderately variable, and the author distinguished two types; he was not, however precise about the age at which the classification was made, nor the detail of the marks on the hairy parts of the body (the face and legs).

LÖFVENBERG and JOHANSSON (1952) recognised the three main classes of EKMAN and inclined towards a scale for grey by noting that only black and white colours were definitive at birth. Grey animals on the contrary were born black, or nearly black, and did not become grey until later. In seeking criteria for distinguishing grey animals from black animals at an early age, SELERUD (I955) investigated the tongue (which is black in black animals) and the underwool which is sometimes white at birth in grey animals. Later the fleece becomes lighter in the adult, becoming almost white in some individuals.

All the analysis of genetic segregation carried out by LöFVENBERG and JOHANSson, however, relied on classifications made at or before the age of sale (between two and five months) without taking account of the colour on the head and feet.

Following these authors, SkÅRMAN recorded the colour shade on the scrotum and tongue, the presence of white underwool at birth and studied their correlation with different shades of grey at four to five months, but as with the previous authors his colour description at four to fives months referred to the colour on the woolly parts of the animals only. In the interval, however, the scale of grey had become extended; LöFvENBERG and JoHANSSON (1952) recognised three grades : light grey, grey and dark grey; there are now five: white-grey, light-grey, grey, dark-grey and grey-black.

\section{Genetic interpretation}

LÖFVENBERG and JOHANSSON (I952) thought at first that the recessive black which they observed was due to a mutant $(g)$ at the locus for wild coloration which they named $G$; and that the white was given by an allele $(W)$ at another locus. They proposed two alternatives to explain grey: an allele or several alleles either at the $G$ locus or the $W$, without being able to distinguish between the two.

Later genetic interpretations by EBBERSTEN and SKÅRMAN (I976), can be summarised as follows:

i) A quantitative inheritance was suggested for the shade of grey with a heritability of shade varying from 0.35 to 0.70 depending on the method of estimation.

ii) A marked effect was found of genes for white markings on fleece colour, increased white markings being in general accompanied by a lighter wool colour. 
iii) The white colour, which is sometimes observed among the Gotland sheep is most likely due to the combined effects of genes for white markings and lack of darkening modifiers.

iv) Black colour in the Gotland sheep may be either due to homozygosity for a gene which is recessive to the gene for grey, or it may be the result of a darkening modifier, which suppresses grey colour.

$v$ ) The grey colour of the Gotland breed was found to be recessive to the white colour of the Swedish Landrace sheep.

\section{III. - Material and methods}

Following the preceding analyses we approached the problem as follows : animals of the improved type were examined to see what colours or colour shades the improved stock had in common with the ancient stock and animals of the latter were examined to see which colour variants could be identified within this breed and which of the variants described by LöFVENBERG and JOHANSSON (1952) were still in existence.

The flocks of Goth sheep available are generally small and dispersed, with a greater concentration in Gotland than on the Swedish mainland, those on the island of their origin were therefore naturally chosen for investigation; this also allowed improved flocks to be visited.

Flocks of the Goth breed surveyed are shown in Table $x$.

TABLEAU I

Flocks of Goth sheep inspected in June 1976 on Gotland $(G)$ and in Stockholm (S) and number of animals grouped by main colour

Troupeaux de moutons Gothiques examinés en juin 1976 dans l'île de Gotland $(G)$ et à Stockholm $(S)$ avec la distribution des animaux selon leur couleur

\begin{tabular}{|c|c|c|c|c|c|c|c|c|c|}
\hline \multirow{2}{*}{ Flocks } & \multicolumn{3}{|c|}{ Rams } & \multicolumn{3}{|c|}{ Ewes } & \multicolumn{3}{|c|}{ Lambs } \\
\hline & Grey & Light & Sum & Grey & Light & Sum & Grey & Light & Sum \\
\hline Lilla Karlsö $(G)^{h}$ - $\cdot \dot{\text {. }}$ & 7 & 0 & 7 & $\cdots$ & $\cdots$ & IOI & 57 & $4 \mathrm{r}$ & 98 \\
\hline Rute (G) . . . . & I & 2 & 3 & 4 & Io & 14 & 8 & 6 & 14 \\
\hline $\begin{array}{l}\text { Erik OHLSson, Vallstena, } \\
\text { Dalhem (G) } \\
\text { Fredrik }\end{array}$ & & $\cdots$ & $\cdots$ & 5 & 4 & 9 & 4 & 12 & I6 \\
\hline $\begin{array}{l}\text { Fredrik WEHTJE, Klintebys } \\
\text { (G) }\end{array}$ & 2 & 3 & 5 & 6 & 8 & I 4 & 7 & 7 & I4 \\
\hline $\begin{array}{l}\text { Sven WAHLBY, Gullgarde, } \\
\text { Rome (G) . . . . }\end{array}$ & o & $\mathbf{I}(\mathbf{1})$ & I & Io & I I & $2 \mathrm{I}$ & 7 & 30 & 37 \\
\hline Skansen Zoo (S) . . . & $\cdots$ & $\cdots$ & $\cdots$ & $\mathbf{I}$ & 4 & 5 & 2 & 3 & 5 \\
\hline $\begin{array}{l}\text { Total } \\
\text { All. exc. Lilla Karlso }\end{array}$ & ro & $\begin{array}{l}6 \\
6\end{array}$ & r6 & $\ddot{26}$ & $\ldots$ & $\begin{array}{r}164 \\
63\end{array}$ & $\begin{array}{l}85 \\
28\end{array}$ & $\begin{array}{l}99 \\
58\end{array}$ & $\begin{array}{r}184 \\
86\end{array}$ \\
\hline All. exc. Lilla Karlso . . & 3 & 6 & 9 & 26 & 37 & 63 & 28 & 58 & 80 \\
\hline
\end{tabular}

(') Only a colour slide available for inspection. 
In the Lilla Karlsö flock all the lambs were described with respect to colour, but the colour of individual ewes in that flock was not recorded. In the Gullgarde flock the colour of both ewes and lambs was recorded, and pedigree records were available on all lambs in that flock. They were all sired by the same sire. In the remaining four flocks, ewes and lambs were claissified into the two groups grey and "light" only. Several of these classifications were made at a distance in the pasture.

\section{A. - The observations}

\section{The Gotland sheep}

In the Gahne flock, which according to Swedish experts is a good average example of present fur producers, the adults appear as follows: the head and legs are black, with lighter areas around the muzzle and the eyes (cf. fig. ra). White markings on the head are present in only few animals. A high proportion of the wool fibres is white, giving the body a near white appearance, but an admixture of black hairs is invariably found.

Lambs observed some time after birth had the same coloration on the feet and the head as their mothers. The coat was grey, the lightness depending on age, consisting basically of a black outer coat with a white underwool. The same descriptions apply equally well to the flock in Scotland.

\section{The Goth sheep}

a) The adults could be classified into two main categories with respect to body colour. The first was a dark grey type, comparable to the improved Gotland, but on the whole showing somewhat darker grey colour on the body, presumably

Fig. I. - Colours of the Goth Sheep

a) dark grey Goth ewe at Lilla Karlsö. One can see the lighter areas around the muzzle and eyes. The colour is very similar with that of the improved Gotland which, has perhaps, a smaller extension of lighter areas.

b) dark grey Goth ewe in Erik OHIsson's flock Vallstena, with the light adult fleece and white markings.

c) Light grey Goth ewe at Lilla Karlsö. One can still distinguish an indistinct type of a grey mouflon pattern.

d) nearly white Goth ewe at Erik OHLSson's flock, most likely of the lightgrey type, with extensive white markings.

e) dark grey Goth Lamb at Seven GUTEMARK's flock, Furillen.

f) grey mouflon Goth Lamb (Links) and agouti Goth Lamb at Lilla Karlsö.

$(a, b, c, d, f)$ photographs by Anna Lena WAssBerG.

\section{Les couleurs du mouton Gothique}

a) Brebis gothique gris foncé a Lilla Karlsö. On voit les zones éclaircies autour du museau et des yeux. La coloration du Gotland amélioré est très semblable avec peut-être des zones éclaircies plus limitées.

b) Brebis Gothique gris foncé dans le troupeau d'Erik OHLsson, avec la toison claire d'adulte et les marques blanches.

c) Brebis Gothique gris clair à Lilla Karlsö. On peut encore distinguer les marques d'un patron mouflon gris.

d) Brebis Gothique presque blanche du troupeau d'Erik OHLsson, probablement du type gris clair avec des marques blanches très étendues.

$e$ )Agneau Gothique gris foncé du troupeau de Sven Gutemark.

d) Agneaux Gothiques à Lilla Karlsö : à gauche mouflon gris, à droite agouti. 


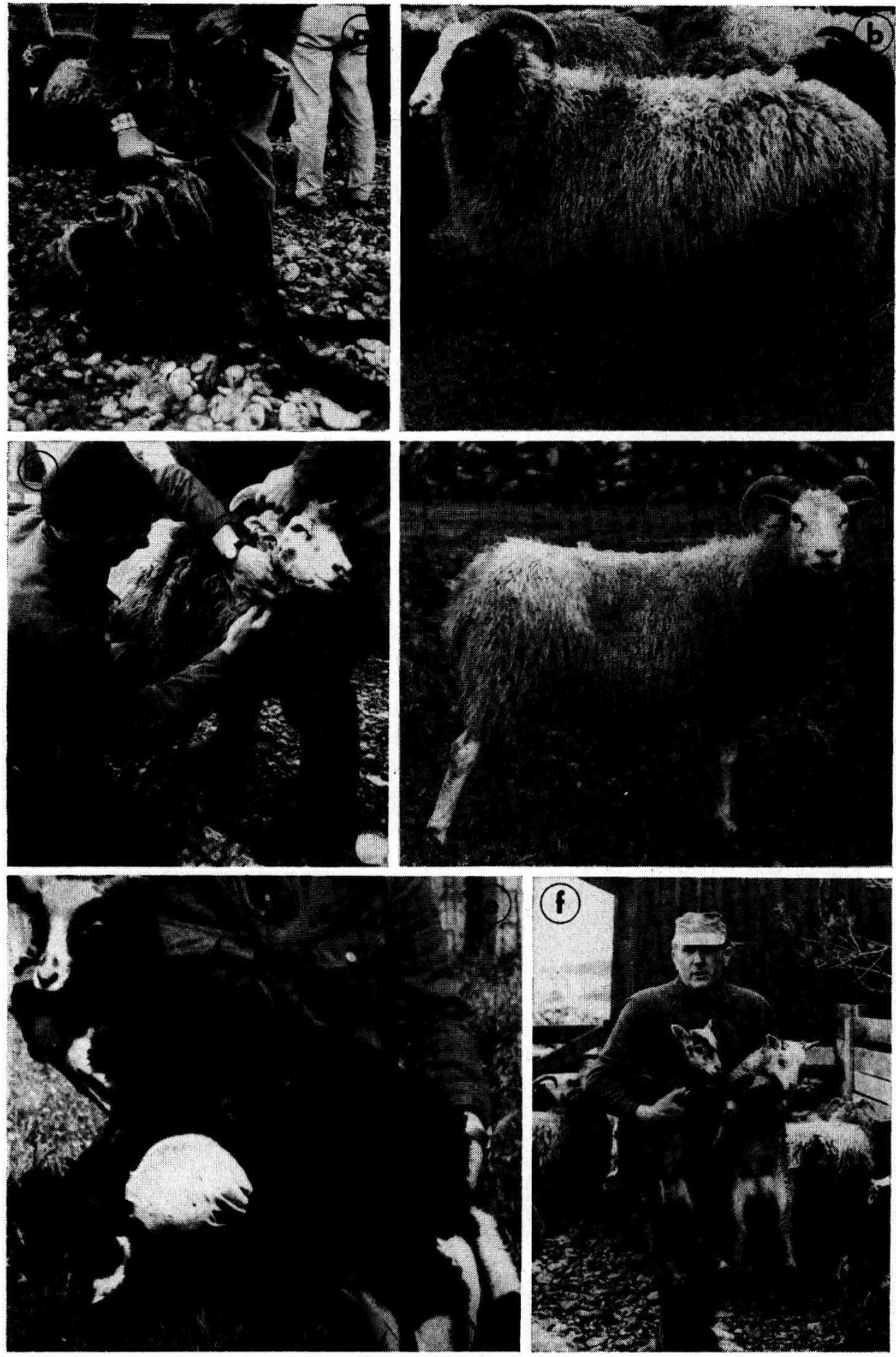


TABLE 2

Distribution of lambs at Lilla Karlsö by sex and colour classes Distribution des agneaux à Lilla Karlsö selon le sexe et la couleur

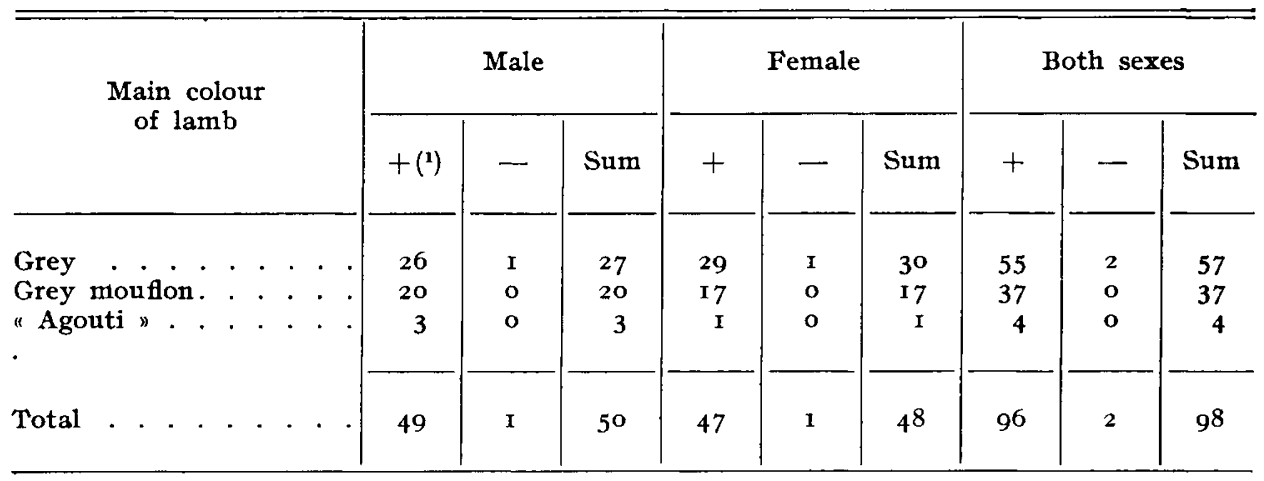

(1) + means presence of white markings.

- means absence of white markings.

due to a coarser outercoat than is found in the improved type. The other type is light grey or near white. The distribution of the adult sheep by these colour classes is shown in Table 1 . See also pictures in fig. ra.b.c.

White markings were common in both types. The white markings were limited to head and feet only in most of the dark types, but covered larger areas in the lighter types. In some of the lightcoloured adults with the least developed white markings one could distinguish and indistinct type of a grey mouflon pattern (or grey reversed badger face). In light-coloured animals with extensive white markings this pattern was possibly present, but obscured. Some of the white sheep like those recorded by LöFVENBERG and JOHANSSON were perhaps of the lightgrey type with extensive white markings (fig. I $d$ ).

b) It was possible to identify three colour classes in lambs which showed limited amount of white markings. The first of these was a dark grey type, similar to the improved type, but sometimes showing white kemp on the belly (fig. I $b$ ). A second type was a distinct type of a grey mouflon pattern with the following characteristics (fig. If) : the upper part of the body was light grey or steel grey in colour, the head showed white colour inside the ear, above the eyebrow and under the chin, and the belly colour was white, all borderlines between grey and white were rather diffuse, which distinguishes this type of grey mouflon from the grey mouflon described in Iceland. The third type of lambs colour was termed " agouti " by the present observers (fig. I $f$ ). This type showed a steel grey colour on the shoulders, which sometimes extended downwards to the flanks. The sides were tan-coloured at the wool tips, while the staple colour varied from steel grey to very light grey. The belly was white with no clearcut borderline between the sides and the belly.

When the lambs showed extensive white markings, it became very difficult to distinguish between the grey mouflon and the "agouti " patterns. They were then only termed " light".

The distribution of the lambs in all the flocks visited on the two classes grey and "light" is shown in Table $I$, and Table 2 shows the distribution of the lambs 
at Lilla Karlsö by sex and the three colour classes grey, grey mouflon and "agouti ». It is evident from Table $I$ that the frequency of grey lambs is significantly higher in the Lilla Karlsö flock than in the other flocks $\left(\chi_{1}^{2}=12.08 ; \mathrm{P}<0.001\right)$.

By assuming that the grey colour in the lambs is due to homozygosity for a recessive gene, the grey mouflon being the heterozygote and the "agouti " the other homozygote, the frequency of the gene for grey is found to be 0.77 in the Lilla Karlsö flock and 0.57 in the other flocks combined. For the Lilla Karlso flock the expected numbers of grey, grey mouflon and "agouti " lambs are 58.I, 34.7 and 5.2 respectively, which is in good agreement with the observed numbers $\left(\chi^{2}=0.45 ; \mathrm{P}>0.05\right)$.

The grey mouflon and "agouti " patterns were not observed among the im proved Gotland sheep. No black animals were seen.

c) The white markings observed in darkgrey lambs and adults were usually a star or a blaze, and in several instances white socks on the feet and a white tail tip was also observed. Extensive piebaldness was rare among the dark greys. In the lighter coloured types the white markings were more extended. The head was sometimes almost completely white, except for some dark around the eyes, and white markings on feet and tail were common.

White markings on head $(\mathrm{H})$, feet $(\mathrm{S})$, tail $(\mathrm{T})$ and body $(\mathrm{P})$ are shown in Tables 2 and 3 for the Lilla Karlsö flock, and in'Tables 4 and 5 for the Gullgarde flock. Only 2 lambs were found without white markings, both on Lilla Karlsö. This gives the frequency of $s$, the recessive gene for white markings, of 0.99 at Lilla Karlsö, and r.oo elsewhere within the Goth breed.

The main colour of the lambs on Lilla Karlsö was found to affect the extent of the white markings significantly, the HST-combination (white head spot socks white tail tip) occuring among only 5 grey lambs out of 55 , compared to I 2 HST lambs out of $4 \mathrm{I}$ with the colours grey mouflon and "agouti " $\left(\chi_{1}^{2}=6.56 ; \mathrm{P}<0.05\right)$.

TABLE 3

Relation between main colour of lambs at Lilla Karlsö and the extent of white markings Corrélation entre la couleur pigmentaire des agneaux à Lilla Karlsö et l'extension des marques blanches

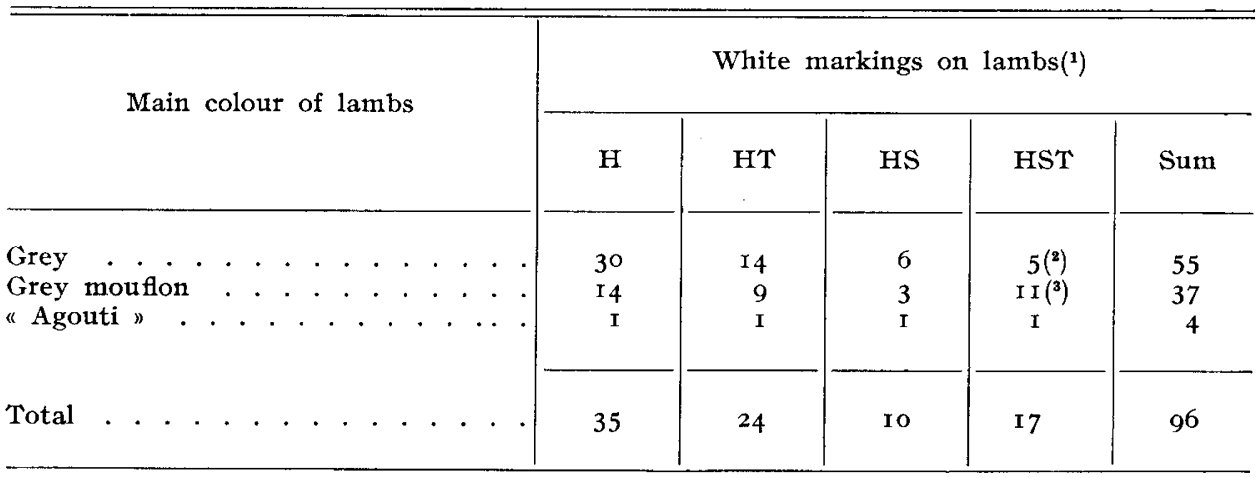

(1) $\mathbf{H}$ : white on top of head.

$T$ : white on tip of tail.

$\mathrm{S}$ : white socks on feet.

(2) On male lamb showing white spots on side.

(3) One male lamb showing white spots on flanks. 
TABLE 4

Classification of lambs at Gullgdrde farm according to colour and extent of white markings and by colour class of dam

Classification des agneaux de Gullgdrde selon la couleur, l'extension des marques blanches et la couleur de leur mère

\begin{tabular}{|c|c|c|c|c|c|c|c|c|c|c|c|c|}
\hline \multirow{3}{*}{ Colour of dams } & \multirow{3}{*}{\multicolumn{2}{|c|}{ No. of dams }} & \multicolumn{6}{|c|}{ Colour of lambs( $\left.{ }^{1}\right)$} & \\
\hline & & & \multicolumn{3}{|c|}{ Grey } & \multicolumn{3}{|c|}{ Grey moufion } & \multicolumn{3}{|c|}{ Light } & \multirow{2}{*}{$\begin{array}{c}\text { No. } \\
\text { of } \\
\text { lambs }\end{array}$} \\
\hline & & & $\begin{array}{l}\mathrm{H}, \\
\mathrm{HS} \\
\mathrm{H}^{\prime} \mathrm{T}\end{array}$ & HST & Sum & $\begin{array}{l}\mathrm{H}, \\
\mathrm{HS} \\
\mathrm{HT}\end{array}$ & HST & Sum & $\begin{array}{l}\mathrm{H}, \\
\mathrm{HS} \\
\mathrm{H}^{\prime} \mathrm{T}\end{array}$ & HST & Sum & \\
\hline Darkgrey & 6 & . . & 4 & 2 & 6 & o & 6 & 6 & o & o & 0 & 12 \\
\hline Grey & 4 & . & o & I & I & I & 2 & 3 & 0 & 'I & I & 5 \\
\hline Grey (mouflon?) & 3 & . & o & o & o & o & 2 & 2 & I & I & 2 & 4 \\
\hline Grey mouflon & 2 & . . & o & o & o & I & 2 & 3 & o & I & $\mathbf{I}$ & 4 \\
\hline Lightgrey & 3 & . . & o & o & o & I & 4 & 5 & o & I & I & 6 \\
\hline Lightgrey piebald & 2 & . . & o & o & o & 0 & 3 & 3 & o & I & I & 4 \\
\hline Lightgrey tan & $\mathbf{I}$ & . . & o & o & o & o & o & o & o & 2 & 2 & 2 \\
\hline Total & $2 \mathrm{I}$ & . . & 4 & 3 & 7 & 3 & 19 & 22 & I & 7 & 8 & 37 \\
\hline
\end{tabular}

(1) See footnote; to Table 3 .

The same was found to hold for the Gullgarde flock, where 3 grey lambs out of 7 showed the HST combination compared to $26 \mathrm{HST}$ lambs out of the remaining $30\left(\chi_{1}^{2}=6.43 ; \mathrm{P}<0.05\right)$. On the other hand the HST combination was significantly more frequent at Gullgårde than at Lilla Karlsö within the same main colour. For the grey lambs the HST combination occured among 5 out of 55 at Lilla Karlsö, but among 3 out of 7 grey at Gullgårde $\left(\chi_{1}^{2}=6.30 ; P<0.05\right)$, and among the non-grey lambs, I2 out of $4 \mathrm{I}$ at Lilla Karlsö and 26 out of 30 at Gullgarde showed the HST combination $\left(\chi_{1}^{2}=22.94 ; \mathrm{P}<0.00 \mathrm{I}\right)$. The concurrence of piebaldness was also found to be significantly more frequent in the Gullgårde flock $\left(\chi^{2}{ }_{1}=59.45 ; P<0.00 I\right)$. This is consistent with a high frequency of modifiers which limit the extent of white markings in the Lilla Karlsö flock and a high frequency of modifiers which increase the extent of white markings in the Gullgarde flock. This is in agreement with the adopted selection practices in the two flocks, emphasis being placed on the dark types on Lilla Karlsö and on the piebald types in the Gullgarde flock.

\section{B. - The segregations}

The classification of the colour of the lambs at the Gullgarde farm by colour classes of the dam is shown in Tables 4 and 5 . The ram used was most likely of the grey mouflon type, but it was dead by the time of the visit, and only a 
colour slide was available for inspection. The classification of the ewes was uncertain, às seen from the tables. The most clearcut category was the dark grey colour. The I2 lambs out of the darkgrey ewes showed only two colours, i.e. 6 were grey and 6 grey mouflon, which is a perfect fit under the assumption that the ram used was a grey/grey mouflon heterozygote. The other results in Tables 4 and 5 are in general agreement with this hypothesis, except for the lack of grey lambs in the lower parts of Tables 4 and 5 .

Observations in the MacDonald flock in Scotland suggested that the relatively dark grey Gotland rams used for breeding there were homozygous grey, because no black lambs were born. A cross made between Gotland rams and ro2 black or brown (moorit) Shetland ewes produced only grey lambs. The lambs were mostly dark, but some were light.

I05: white Shetland ewes mated with a Gotland ram produced white and grey lambs roughly in the proportion I : $I$, indicating that a high proportion of the ewes were heterozygous white.

TABLE 5

Classification of lambs at Gullgårde farm according to colour and occurence of piebaldness, and by colour class of dam

Classification des agneaux de Gullgarde selon leur couleur, la présence de panachures et la couleur de leur mère

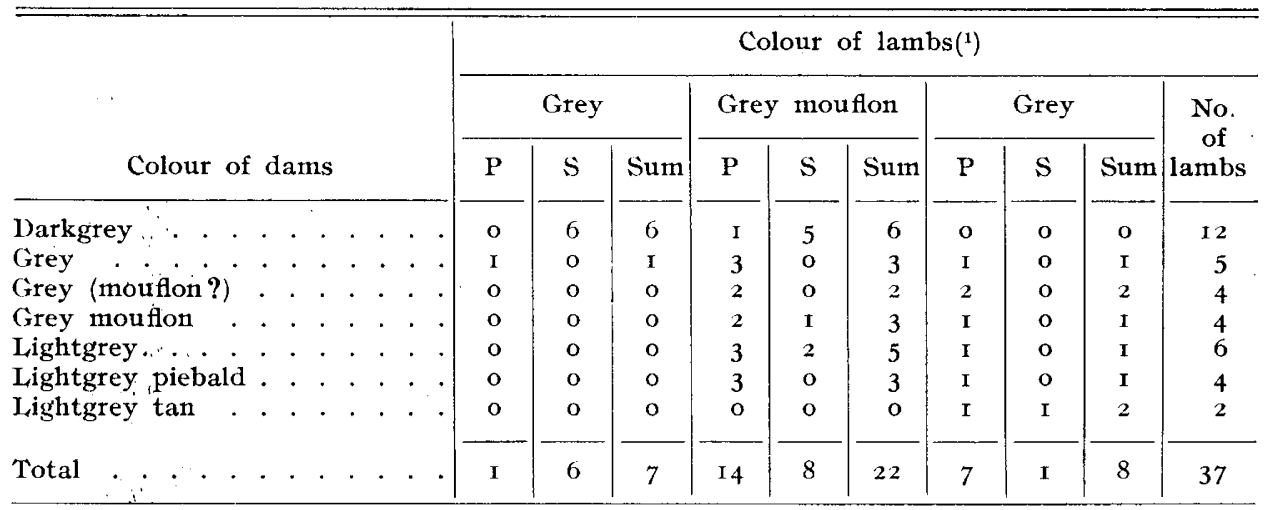

(') P : means piebald, i.e. white patches on body.

S : means solid colour, i.e. no white patches on body.

\section{Discussion}

It was shown by AdALSTEInsson (1970) that non white Icelandic sheep possessed either black or brown pigment (presumably eumelanin), the black pigment being produced by a dominant gene $B$ and the brown pigment by the recessive allele, $b$. The recessive brown genotype $b b$, is found in the brown Icelandic sheep and in the moorit Shetland sheep (for the link between past and present gene symbols see AdALs'TEINSSON, I974).

Genes at the $A$ gouti locus modify the pigment produced by the genes at the $B$-locus to a greater or less extent. The top dominant allele at the $A$-locus, $A^{w h}$, produces white or tan (red) colour, the intermediate alleles $A^{b}, A^{w}$ and $A^{g}$ 
produce the patterns or colours badgerface, mouflon (reversed badgerface) and grey, and the bottom recessive allele, $a$, has no effect on black or brown pigment, producing selfcolour (black or brown) when homozygous.

It will be assumed that the above rules hold for the breeds under discussion in the present study except where otherwise stated.

\section{I. - The Gotland sheep}

The grey of the improved type has several of the characteristics of the grey at the $A$ gouti locus found in Iceland, but differs from it some aspects.

The results from the cross made in Scotland between grey Gotland rams and black and brown Shetland ewes show that the grey gene is dominant to lack of grey in the black or brown Shetland ewes, that the rams used were most likely homozygous, $B B$, for the gene for black pigment, and that the relatively dark grey Gotland rams were most likely homozygous for the gene producing the Gotland grey colour. This last piece of evidence possibly indicates that the Gotland grey is not produced by $A^{g}\left(A_{2}\right)$ found in Iceland, because one the characteristic features of $A^{g}$ is the much lighter colour of the homozygotes than the heterozygotes (ADALSTEINSSON, I970).

EBBERSTEN and SkÅRMAN (I976) inferred that they had found rams which were heterozygous for the grey gene within the Gotland breed. These rams were themselves darker than other rams, and there grey progeny was also on the average darker than the progeny of other rams. This indicates that the effect of the grey gene within the improved Gotland breed is comparable to the $A^{g}$-gene within the Icelandic breed, i.e. that neither gene is completely dominant to the recessive $a$, which in homozygous form gives black colour.

EBBERSTEN and SKÅRMAN further showed that the Gotland grey colour was recessive to the white colour of the short-tailed Swedish Landrace sheep. Their backcross of white (Swedish-Landrace $\times$ Gotland) ewes to grey Gotland rams produced only two colours, i.e. white (or tan piebald) and grey in the ratio I : I.

Two independant pieces of evidence suggest that selection for darkening modifiers of grey has been carried out whithin the improved Gotland breed. EBBBERTEN and SkARMAN (I976) found that grey lambs from the cross white (Landrace $\times$ Gotland) ewes $\times$ Gotland rams were of an appreciably lighter shade than the average within the improved Gotland. In the MacDonald flock in Scotland it was also observed that the backcross white (Shetland $\times$ Gotland) $\times$ Gotland produced grey lambs which were mainly light grey.

This, viewed in light of the selection against light types described by EBBERSTEN and SKÅRMAN (I976), together with the relatively high heritability they found for shade of grey, mentioned previously, alos points to selection for darkening modifiers. From the evidence presented here one feels that the following conclusions are permissible.

i) The Gotland grey is situated at the Agouti locus.

ii) It may and often does produce a dark grey colour in the homozygote.

iii) Selection for darkening modifiers has been carried out within the Gotland breed.

iv) The Gotland grey is produced by an allele which is very similar from $A^{g}\left(A_{2}\right)$ found in the Icelandic sheep and possibly also in Corsica (LAUVERGNE and Adalsteinsson I976) but perhaps distinct. Provisionally we propose the name $A^{g g}$ ( $g g$ for (improved) Gotland grey) for this apparently new allele at the Agouti locus. 
Ann. Génét. Sél anım., 1978, 10 (2), 191-208.

\section{Erratum}

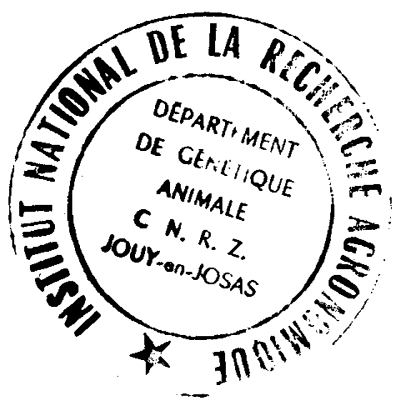

Fréquence du syndrome d'hyperthermie maligne dans des populations porcines françaises; relation avec le développement musculaire

L. OLIIVIER, P. SELLIER et G. MONIN(*)

avec la collaboration technique de Marie-Reine Langlois, P. Dando, C. FeLGines, A. Talmant (*), D. TASTU et P. VERNIN (*)

Station de Génétique quantitative et appliquée, Centre national de Recherches zootechniques, I.N.R.A., 78350 Jouy-en-Josas

$\left(^{*}\right)$ Station de Recherches sur la viande,

Centre de Recherches de Clermont-Ferrand, I.N.R.A., Theix, 63rio Beaumont

Page $197: 3^{\mathrm{e}}$ ligne et suivantes lire :

...Pour le Large White, la limite supérieure de l'intervalle de confiance de la fréquence génique, correspondant à une probabilité inférieure à 5 p. I00 de ne trouver aucun positif dans l'échantillon étudié, est égale à 0,17 en supposant une pénétrance complète. Les estimations... 
. 


\section{2. - The Goth sheep}

The Goth sheep shows a considerably greater variation than the improved type, as mentioned earlier. The three phenotypes observed among the lambs at Lilla Karlsö are consistent with a two-allele case, the dark grey lambs being homozygous $A^{g g} A^{g g}$, the grey mouflon lambs being $A^{g g} A^{l g}$ ( $l g$ for light grey) and the "agouti "lambs being homozygous $A^{\lg } A^{l g}$.

It is obvious from the studies on the improved Gotland sheep cited earlier that a more pronounced colour variation was encountered in the study of LörvENBERG and JohANSSON (1952) than one finds today. The grey mouflon pattern found in the Goth sheep of today might for example have existed in the flock that LöFVENBERG and JoHANSSON studied, but selection against unfavourable, highly beritable traits would soon have eradicated such a gene if it had occurred at a low frequency.

The segregation of the two alleles postulated in the Goth sheep at Gulgairde near Roma is not clearcut. One should bear in mind that white markings were found to be more pronounced in the Gulgårde flock than in the Lilla Karlsö flock, and this may have obscurred the picture.

The existence of a separate allele producing the light colour which the present authors have termed grey mouflon is not at all firmly established, but the type of grey mouflon pattern observed in the Lilla Karlsö lambs is consistent with the hypothesis that this light colour is produced by a single gene.

It is also possible that the gene for tan or white $A^{\text {wh }}$ quite common in Iceland which probably was in the genetic formula of the white animals described by LöFVENBERG and JOHANSSON (I952) is still present in some flocks we have checked even if sometimes $A^{w h}$ it is mimicried by $\left(A^{l g} A^{l g}\right)$.

Rę̧u pour publication en décembre 1978 .

\section{Acknowledgments}

This research project was encouraged and partially supported by the Department of animal Breeding, the Agricultural College of Sweden, Uppsala 7 (Professors K. RönNINGEN, B. GAHNE and E. Brannang). Our trip in Gotland was prepared and guided by R. EDBERG, H. HALI,ANDER and Anna Lena WASSBerg who took the photographs.

The kind assistance of the breeders has been also greatly appreciated.

\section{Résumé}

Possible interprétation génétique des variants colorés de la toison des moutons Gothique et Gotlandais

On décrit la couleur de 79 adultes et de $I 84$ agneaux en provenance de 6 troupeaux de 1'ancienne race suédoise cornue, à queue courte, le mouton Gothique. Parmi les adultes il y avait 36 gris et 43 presque blancs, cependant que 85 des agneaux étaient gris et 99 de couleur claire. Les agneaux de couleur claire avec une extension limitée de taches blanches présentait soit un patron gris clair avec le ventre blanc appelé " mouflon gris " soit un mélange de gris acier clair et de fauve appelé " agouti ".

Les marques blanches étaient fréquentes dans tous les troupeaux, et lorsqu'elles étaient étendues, elles rendaient parfois difficile l'identification du patron pigmenté. 
Sur la base d'observations sur le mouton Gothique avec quelques examens de croisés Gotlandais gris et Shetland faits en Écosse et d'une revue de la littérature on pense que la couleur grise de l'ancien mouton Gothique et du Gotlandais amélioré est due à un nouvel allèle en $A$ gouti $A$ og ( $g g$ pour Gotland grey) à moins que ce ne soit le même allèle que $A^{g}$ (icelandic grey). La couleur mouflon gris du mouton Gothique serait due à un autre allèle encore non décrit $A^{l g}$ (lg pour Light grey) au locus $A$ gouti. Quelques animaux blancs peuvent être $A^{l g} A^{l g}$ ou même porter le gène $A$ wh pour le fauve ou le blanc.

\section{References}

Adalsteinsson, S., 1960. Inheritance of coat colour in sheep. Freyr, 56, 385-391.

Adalsteinsson, S., 1970. Colour inheritance in Icelandic sheep and relation between colour, fertility, and fertilization. J. Agric. Res. Iceland, 2, 3-1 35.

ADALSTEINSSON, S., I974. Colour inheritance in farm animals and its application in selection. Ist World Congress on Genetics applied to Livestock Production. Madrid, 7-II October I974, 1, 29-37.

Brooker M. G., Dolling C. H. S., I969. Pigmentation of sheep. II. The inheritance of colour patterns .n black merinos. Austr. J. Agric. Res., 20, 387-394.

EBBERSTEN K. and SKáRMAN S., 1976. Colour changes and colour inheritance in Swedish

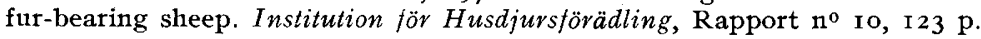

EDBERG R., I974. De behornade gotländska utegångåsfren - deras ursprung och framtid. Fauna og Flora, 69, 193-202.

EkmaN S., I938. Våra husdjurs gamla lantraser bör bevaras. Sveriges Natur, 29, 23-46.

EKman S., I964. Das Gotlandsschaf. Z. Säurgetierk, 3, I29-I45.

GAHNE B., DANEl, O. and SJögren T., 1975. Fur skin characteristics and breeding of the

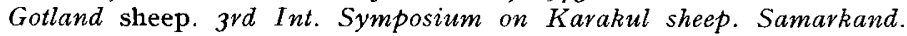

Glembosky J., Diaskov J., Krimskaia E., 1934. Shirazi homozigote letal (russian). Biol. Jurn., 3, 366-382.

HALl_ANDER H., 1976. Gutefår - vår äldsta fårras - på frammarsch, Färskötsel, 56 (2), 5-8.

LAUVERGNE J. J., I975. Génétique de la couleur de la toison des trois races ovines françaises Bervichonne, Bizet et Solognote. Ann. Génét. Sél. anim., 7, 263-276.

LAUVergne J. J. and Adalsteinsson S., i976. Gènes pour la couleur de la toison de la brebis Corse. Ann. Génét. Sel. anim., 8, I53-1 72.

LöFVENBERG S. and JOHANSSON J., I952. Über die Farbenvererburg beim gotländischen Landschaf. Z. Tierzucht. ZüchtBiol., 60, 252-262.

RAE A. L., 1956. The genetics of the Sheep. Adv. Genet., 8, 189-265.

RYDER M. L., I 968 . Fleece structure in some native and unimproved breeds of sheep. Z. Tierzucht. ZüchtBiol., 85, I43-I 70.

RYDER M. L., I970. Sheep in Scandinavia. Span, 13, 5I-53.

RYDER M. L., I 974. Fleece measurements of some miscellaneous native and unimproved breeds of sheep. J. Text. Inst., 65, I3-I9.

Ryder M. I., LAND R. B. and Ditchburn R., 1974. Colour inheritance in Soay, Orkney and Shetland sheep. J. Zoology, London, 173, 477-485.

RYDER M. L. and STEPhenson S. K., I968. Wool Growth. Academic Press, London and New York.

SEARLE A. G., 1968. Comparative genetics of coat colour in mammals. Logos Press, Academic Press, London and New York, I89-I94.

SELERUD A., I955. Undersökning av sambandet mellan tungfärgen vid födelsen ochullfärgen vid 5 månaders ålder hos lamm av svenska landtrasfår Svenska fåravelsfören tidskr., 35, I 5 I-I 55 .

Serra J. A., I948. Génétique du Mouton. Publ. Junta Pecuar, Lisboa (ser. A) no I, 14-75.

SkÅRmAN S., r96r. Färgstudier hos Gotlands utegångsfår I. Fårskötsel, 41, 62-67.

SkÅRMAN S., I963a. Färgstudier hos Gotlands utegångsfår II. Fårskötsel, 43, 39-43.

SkÅrman S., 1963b. Färgstudier hos Gotlands utegångsfår III. Fårskötsel, 43, I $27-135$.

Zachakra G., I939. Recherches sur la dépigmentation de la laine des moutons de race Karakul. Ann. Inst. Nat. Zootech. Roumanie, 7, 100-1 18. 